\title{
Importance of the Choice of a Recombinant System to Produce Large Amounts of Functional Membrane Protein hERG
}

\author{
Lucie Vasseur ${ }^{1}$, Thierry Cens ${ }^{1}$, Renaud Wagner ${ }^{2}$, Nathalie Saint ${ }^{3}{ }^{\circledR}$, Valérie Kugler ${ }^{2}$, \\ Alain Chavanieu ${ }^{1}{ }^{(1)}$, Christine Ouvry ${ }^{4}$, Clémence Dupré ${ }^{4}$, Gilles Ferry ${ }^{4}$ and Jean A. Boutin ${ }^{5, *}$ \\ 1 Institut des Biomolécules Max Mousseron, Université de Montpellier, 34090 Montpellier, France \\ 2 Plateforme IMPReSs, CNRS UMR7242, Biotechnologie et Signalisation Cellulaire, \\ Ecole Supérieure de Biotechnologie de Strasbourg, 67400 Illkirch, France \\ 3 PHYMEDEXP, Université de Montpellier, CNRS, INSERM, 34090 Montpellier, France \\ 4 PEX Biotechnologie, Chimie \& Biologie, Institut de Recherches SERVIER, 78290 Croissy-sur-Seine, France \\ 5 Institut de Recherches Internationales SERVIER, 92150 Suresnes, France \\ * Correspondence: jean.boutin@servier.com; Tel.: +3-315-572-4400
}

Received: 4 June 2019; Accepted: 27 June 2019; Published: 28 June 2019

\begin{abstract}
Human ether-a-gogo related gene (hERG) product is the membrane potassium channel Kv11.1, which is involved in the electrical activity of the heart. As such, it is a key player in the toxicity of many drug candidates. Therefore, having this protein at hand during earlier stages of drug discovery is important for preventing later toxicity. Furthermore, having a fair quantity of functional channels may help in the development of the necessary techniques for gaining insight in this channel structure. Thus, we performed a comparative study of methods for over-expressing a mutated but functional, hERG in different orthologous hosts, such as yeast, bacteria, insect and human cell lines. We also engineered the protein to test various constructs of a functional channel. We obtained a significant amount of a functional mutant channel from HEK cells that we thoroughly characterized. The present work paves the way for the expression of large amounts of this protein, with which protein crystallization or cryo-electronic microscopy will be attempted. This will be a way to gain information on the structure of the hERG active site and its modelization to obtain data on the pauses of various reference compounds from the pharmacopeia, as well as to gain information about the thermodynamics of the hERG/ligand relationship.
\end{abstract}

Keywords: hERG; Kv11.1; P. pastoris; E. coli; HEK cells; expression; purification; functional characterization; baculovirus expression system

\section{Introduction}

Membrane proteins include receptors, transporters and channels. Approximately one-third of eukaryotic genes are estimated to encode membrane proteins [1]. Integral membrane proteins (IMPs) are often called "gatekeepers of the cell" [2] in reference to their crucial role in regulating the flow of information and compounds across the plasma and intracellular membranes. They are known to be involved in a number of vital cell functions, including homeostasis, growth and differentiation and neural signalling. Because of the difficulty in determining the structures of IMPs compared to globular and soluble proteins, the molecular mechanisms of action are not often described in the literature, in particular regarding the biophysics of the interaction with its ligands. Moreover, IMP research would aid in drug development, as these proteins are usual drug targets, playing key roles in a broad spectrum of human hereditary and somatic disorders and diseases [3]. Furthermore, membrane proteins are the molecular targets of roughly $40 \%$ of all FDA-approved drugs [4]. The first atomic-resolution structure 
of a membrane protein was published in 1985 for the photosynthetic reaction centre L-M complex [5]. In more than 40 years, the number of resolved IMP structures is still extremely low, less than $1-2 \%$ of the total protein depositions in the Protein Data Bank (PDB), which translates as 600 unique membrane protein structures in 2016 [6] and nearly 900 today (https://blanco.biomol.uci.edu/mpstruct) but it only doubled over the last 20 years [3]. The introduction and regular use of techniques linked to cryo-electron microscopy, as opposed to crystallography and X-ray diffraction may change this ratio in the coming years [7]. It is more and more common to use partially purified IMPs to obtain biophysical data [8], particularly to understand the ligand/IMP relationship at a thermodynamic level [9].

Providing large amounts of a pure protein is the first critical step toward structural and biophysical studies. Heterologous recombinant systems are commonly used to get around the presence of low amounts of IMPs in native cells. The historical production system is the bacteria Escherichia coli. Low cost, ease of use, availability of expression vectors and the possibility of labelling the protein are some of the well-known advantages of $E$. coli [10]. Nevertheless, a large proportion of eukaryotic membrane proteins appear to be aggregated and misfolded when expressed in bacteria [11]. This phenomenon is predicted to occur with one-third to one-half of prokaryote proteins and an even higher proportion of eukaryotic proteins [12]. The production of milligrams of pure, authentically folded protein is more often performed with yeast (i.e., Pichia pastoris), insect or mammalian cells rather than E. coli. A number of specific production strategies have been developed for each of those host systems. Interestingly, the approach to G-protein coupled receptor pharmacology helped develop a series of techniques to address as many of the problems of IMP expression and purification as possible [13-15]. Considerable progress has been published on the reconstitution of such proteins and their capacity, once reconstituted, to be functional [13-15] but $>99 \%$ sample purity is still challenging in crystallization success. Such a purity standard is often far from our immediate grasp for membrane proteins. Furthermore, low expression levels are still frequently reported for IMPs [11] and it is obvious that reaching high levels of recombinant protein expression will permit to purify to a decent yield this difficult category of proteins.

The human-ether-a-go-go related gene (hERG) encodes the voltage-activated potassium channel Kv11.1 [16]. This ionic channel is predominantly involved in cardiac rhythm with crucial action in cardiomyocyte repolarization [16]. It is also expressed, though to a lesser extent, in the nervous system, jejunum and endocrine system. This channel is a non-specific target of a variety of structurally diverse drugs [17]. This unwanted blockage of hERG function by drugs can lead to long QT syndrome (LQTS), causing severe heart conditions [18,19]. In this context, regulators and pharmaceutical companies are concerned, establishing tests to detect drug-induced pro-arrhythmic risk at early phases of drug discovery. Verification that a drug candidate at its earliest stage of qualification does not bind to hERG is key to pursuing drug development. During the last decade, a considerable number of studies have focused on this channel from pharmacological and technological points of view $[17,20]$. The potassium permeable pore is a homo-tetrameric assembly of hERG subunits. Each 1159-amino-acid monomer constitutes a transmembrane domain containing six alpha-helices [16]. The helices from $\mathrm{S} 1$ to $\mathrm{S} 4$ are responsible for the voltage sensor activity of the channel [21,22]. The pore domain is comprised of S5 and S6 helices and a pore helix (P) between S5 and S6 [23]. The N- and C-termini contain 400 and 500 amino acids, respectively and are located in the cytoplasmic compartment [16,24]. Similar to other IMPs, hERG structural studies have been hindered by several difficulties, such as recombinant production in large amounts as well as solubilizing and purifying a functional stable protein. Interestingly, the most recent work on the hERG structure used cryo-electron microscopy after production in a HEK cell line infected by a virus encoding a truncated version of the protein [24]. In 2013, Hausammann and Grütter [25] published a study in which they engineered a minimal construct based on the hERG sequence. This construct contained the whole membrane domain of hERG with six alpha-helices but omitted both the $\mathrm{N}$ and $\mathrm{C}$ terminus cytoplasmic extremities. After truncation, an artificial tetramerization domain in the $C$ terminus, the GCN4-LI leucine zipper [26], was added. This 33-amino-acid peptide forms an extremely thermostable tetrameric parallel coiled-coil. This minimal 
chimeric channel was shown to be functional by recording currents using two electrode voltage clamps in xenopus oocytes [25].

In the present study, we present several strategies for the expression, purification, reconstitution and characterization of the chimeric version of hERG(S1-coil) described by Hausammann and Grütter [25]. We started by generating and producing the protein in three recombinant systems. The amount of total functional channel produced was investigated. We also tested the capacity of non-ionic and zwitterionic detergents to extract the channel from membranes before proceeding to its purification. Purified hERG channels reconstituted in planar lipid bilayers were functionally evaluated by electrophysiology.

\section{Results and Discussion}

For biophysical in vitro studies and structural investigations of proteins, a large amount of material in the range of milligrams is usually required. With membrane proteins, recombinant systems over-expressing the gene of interest are required because of their typical low abundance in their natural hosts [27]. Because no universal system is readily available for this purpose, our first task was to identify the best recombinant sequence to introduce into the most appropriate production system. Our attempts to produce the human hERG(S1-coil) channel in bacteria failed at the initial step of this study (see details below, Section 2.2), so we selected a panel of three representative expression systems shown to be efficient for over-expressing several membrane proteins: the eukaryotic microorganism P. pastoris [28-31], the Sf9 insect cell line [32] and the human HEK cell line used for transient expression or stable and inducible expression [33,34]. We also fused various tag sequences to the channel cDNA based on their proven benefits with regard to detection, purification and/or protein stability. For a better understanding of our strategy, we report in Figure S1 the sequence of the wild type hERG and in Figure S2, the actual sequences we used in the present work.

\subsection{Analysis of hERG(S1-coil) Function in Xenopus Oocytes}

First, we confirmed activation gating of the chimera hERG(S1-coil) channel using the voltage-pulse protocol in Xenopus laevis [25]. As shown previously, hERG(S1-coil) has very similar gating characteristics as wild type hERG. The Boltzmann fit of the I-V data revealed a half-maximal activation $\left(\mathrm{V}_{1 / 2}\right)$ of $-27.7 \pm 2.3 \mathrm{mV}$ for hERG(S1-coil) and $-33.3 \pm 0.9 \mathrm{mV}$ for hERG-wt and a slope $(k)$ of $6.0 \pm 0.4 \mathrm{mV}$ for hERG(S1-coil) and $7.5 \pm 0.4 \mathrm{mV}$ for hERG-wt (Figure 1A,B). In addition, inhibition by E-4031 and the BeKm-1 toxin had close IC $_{50}$ for hERG(S1-coil) $(24.87 \pm 3.77 \mathrm{nM}$ with BeKm- 1 and $2.3 \pm 0.2 \mu \mathrm{M}$ with E-4031) and hERG-wt $(21.67 \pm 2.76 \mathrm{nM}$ with BeKm-1 and $2.5 \pm 0.3 \mu \mathrm{M}$ with E-4031) (Figure 1C,D). These results are comparable to those from the literature [25,35] and demonstrate that the replacement of $h E R G$ inherent tetramerization domains by a leucine zipper motif maintains oligomeric stability and channel function. 
A

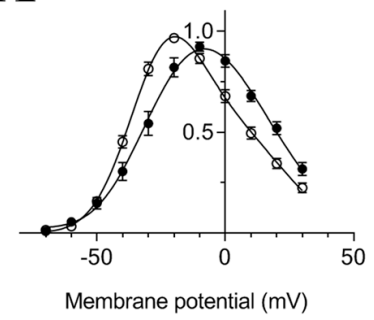

B

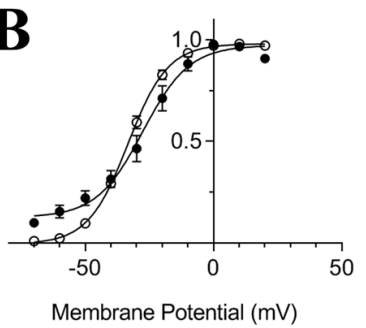

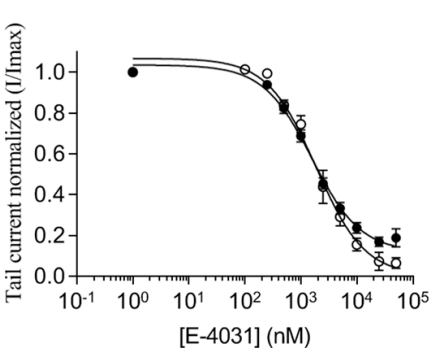

C

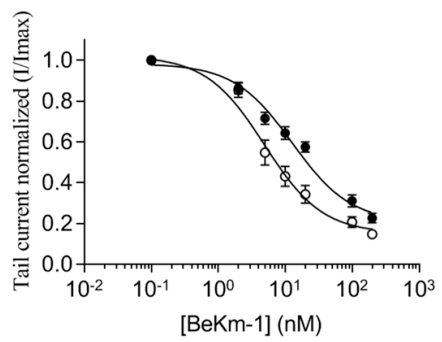

D

Figure 1. Voltage activation and pharmacological properties of hERG(S1-coil) recorded in Xenopus oocytes. (A). Current-voltage relationship for hERG-wt and hERG(S1-coil). Currents measured at the end of a 4 seconds long depolarizing pulse (from -70 to $30 \mathrm{mV}$ ) were normalized to the maximal current for hERG-wt $(n=21)$ and hERG(S1-coil) $(n=19)$. (B). Steady-state voltage-dependence of activation. The tail currents at $-50 \mathrm{mV}$ were normalized to the peak tail current, plotted against the amplitude of the depolarizing pulse and fitted with a Boltzmann function to estimate the potential for half-activation $(\mathrm{V} 1 / 2)$ and the slope value $(\mathrm{k})$ for hERG-wt $(\mathrm{V} 1 / 2=-33.3 \pm 0.9 \mathrm{mV}, \mathrm{k}=7.5 \pm 0.4 \mathrm{mV}, n=21)$ and $\mathrm{hERG}(\mathrm{S} 1$-coil $)(\mathrm{V} 1 / 2=-27.7 \pm 2.3 \mathrm{mV}, \mathrm{k}=6.0 \pm 0.4 \mathrm{mV}, n=19)$. Note that the values obtained with hERG(S1-coil) are significantly different from those obtained with hERG-wt $(p<0.01)$. (C). Inhibition curves for hERG-wt $(n=9)$ and for hERG(S1-coil) $(n=13)$ by E-4031 determined by measuring the tail current at $-40 \mathrm{mV}$ in the presence of increasing concentration of E-4031 and normalized to the control current measured in the absence of drug at a voltage of $-40 \mathrm{mV}$ after 2 seconds of depolarization at $+20 \mathrm{mV}$. Curves are fitted with a logistic function. (D). Inhibition curves for hERG-wt $(n=7)$ and for hERG(S1-coil) $(n=8)$ by the BeKm-1. hERG wild type = empty circles; hERG(S1-coil) = filled squares.

\subsection{Comparison of Functional hERG(S1-coil) Expression in Different Systems}

Four expression protocols were followed to produce the hERG(S1-coil) chimera channel. The Sf9 (Spodoptera frugiperda) insect cell line, P. pastoris and mammalian HEK cell line (transient or stable expression) were tested according to the protein constructs described in Table 1. For expression in Sf9 cells, the sequence 2Strep-3C-hERG(S1-coil)-TEV-6His was integrated into baculovirus, followed by viral infection. In the yeast $P$. pastoris, the hERG(S1-coil)-10His production was induced after integrative transformation. Finally, two different approaches were tested for expression in the HEK cells: FreeStyle transient transfection and the generation of an inducible stable cell line by lentiviral transduction. For expression in HEK cells, the hERG(S1-coil)-TEV-SBP-6His construct bearing a N598Q mutation at the glycosylation site was produced to increase the homogeneity of over-expressed protein. 
Table 1. Overview of hERG(S1-coil) channel production in different recombinant systems.

\begin{tabular}{|c|c|c|c|c|}
\hline \multirow{2}{*}{ System of Expression } & \multirow{2}{*}{ YEAST: P. pastoris } & \multirow{2}{*}{ INSECT CELLS: Sf9 } & \multicolumn{2}{|c|}{ MAMMALIAN CELLS: FreeStyle ${ }^{\mathrm{TM}}$ 293-F Cells } \\
\hline & & & Transient Production & Stable and Inducible Cell Line \\
\hline Plasmid & pPIC9K & pFB1 & pCI-neo & Lentivirus rLV.TRE3G \\
\hline Expression mode & $\begin{array}{l}\text { Integrative transformation in } \\
\text { SMD1163 }\end{array}$ & Infection by baculovirus & Transfection by electroporation & Lentivirus transduction \\
\hline Induction of gene expression & Methanol & Viral infection & & Doxycycline \\
\hline Construct & \multicolumn{4}{|c|}{ hERG(S1-coil) } \\
\hline Sequence & hERG(362-675) + coiled-coil & hERG(362-675) + coiled-coil & \multicolumn{2}{|c|}{ hERG(362-675) + coiled-coil } \\
\hline N-ter tags & None & $2-$ Strep $+3 C$ & \multicolumn{2}{|c|}{ None } \\
\hline Mutation & None & None & \multicolumn{2}{|c|}{ N589Q } \\
\hline C-ter tags & $10-\mathrm{His}$ & $\mathrm{TEV}+6$-His & \multicolumn{2}{|c|}{$\mathrm{TEV}+\mathrm{SBP}+6-\mathrm{His}$} \\
\hline Number of AA & 373 AA & $407 \mathrm{AA}$ & \multicolumn{2}{|c|}{$411 \mathrm{AA}$} \\
\hline Monomeric protein & $42,025 \mathrm{Da}$ & $45,701 \mathrm{Da}$ & \multicolumn{2}{|c|}{$46,389 \mathrm{Da}$} \\
\hline Tetrameric channel & $168,099 \mathrm{Da}$ & $182,803 \mathrm{Da}$ & \multicolumn{2}{|c|}{$185,555 \mathrm{Da}$} \\
\hline
\end{tabular}


Moreover, we experimented several expression conditions in various E. coli strains. The DNA sequence of hERG(S1-coil) has been codon-optimized for expression in E. coli and integrated into the pET32a vector (Novagen) with a TEV sequence and a 6 His tag in C-terminal. The recombinant plasmid has been transformed into different three E. coli strains: BL21(DE3)pLysS (Invitrogen), Rosetta-gami(DE3)pLysS (Novagen) and C41(DE3)pLysS (Lucigen). Expression was induced at an OD600 between 0.4 and 0.6 in LB medium by the addition of 0.1 or $1 \mathrm{mM}$ of IPTG (isopropyl $\beta$-D-1-thiogalactopyranoside). We carried out several time courses at different temperatures, such as 15,28 and $37^{\circ} \mathrm{C}$. Nevertheless, SDS-PAGE and Western Blot analysis of both the total and the insoluble fractions of bacteria did not indicated any presence of the protein of interest (not shown).

After expression in each system, the level of functional channel was quantified by ligand-binding studies on membrane preparations using $\left[{ }^{3} \mathrm{H}\right]$-dofetilide as the tracer ligand (Figure 2). The saturation format used in these binding studies allowed the determination of a $B_{\max }$ value for each sample, which represents the maximal amount of ligand required to saturate a population of receptors, and thus an estimation of the number of receptors present in the sample. The $\mathrm{K}_{\mathrm{D}}$ parameter, which corresponds to the ligand concentration needed to saturate half of the binding sites, reflects on the affinity of the receptor for its ligand (Table 2). While the $K_{D}$ values are globally consistent between the different expression systems tested, the calculated $\mathrm{B}_{\max }$ is particularly low in the case of production in Sf9 cells and transient HEK $(0.70 \pm 0.10$ and $0.73 \pm 0.04 \mathrm{pmol} / \mathrm{mg}$ of membrane proteins, respectively). The generation of a stable cell line with the capacity to express hERG(S1-coil) by doxycycline induction resulted in a 7-fold enhancement of functional channels in membranes, with $5.04 \pm 0.2 \mathrm{pmol} / \mathrm{mg}$ of membrane proteins calculated for the $B_{\max }$ value. Integration of the protein sequence into the cell genome allows stable genetic transmission in each cell, as the plasmid tends to be lost after transitory transfection. Second, the stable cell line has the capacity to be induced in a way that avoids the risk of cell toxicity usually reported in constitutive expression [36]. Surprisingly, the best $\left[{ }^{3} \mathrm{H}\right]$-dofetilide binding $B_{\max }$ value of $12.0 \pm 0.3 \mathrm{pmol} / \mathrm{mg}$ of membrane proteins was recorded after production in P. pastoris (see Table 2 for details). Although the HEK cell line is the most homologously similar system to the physiological environment of the hERG channel, P. pastoris allowed the higher expression of functional channel. We focused on both P. pastoris and the stable HEK cell line in subsequent steps.

The relative variability of the $B_{\max }$ and $K_{D}$ values that is observed between the different batches in Table 2 is a common issue with the overexpression of membrane proteins. Even if such an observation is poorly documented in the literature, some studies have already illustrated this aspect (see Logez et al. [13]). Such heterogeneity is likely to be related to the overloading of the cell machineries during the massive production of membrane proteins that is potentially triggering unfolding response pathways. These events may then vary from batch to batch, ending with variable levels of functional proteins. This is particularly the case with mammalian cells expression systems where some factors that are less controlled (culturing medium lots, number of cell passes) may have a significant impact on these aspects. 


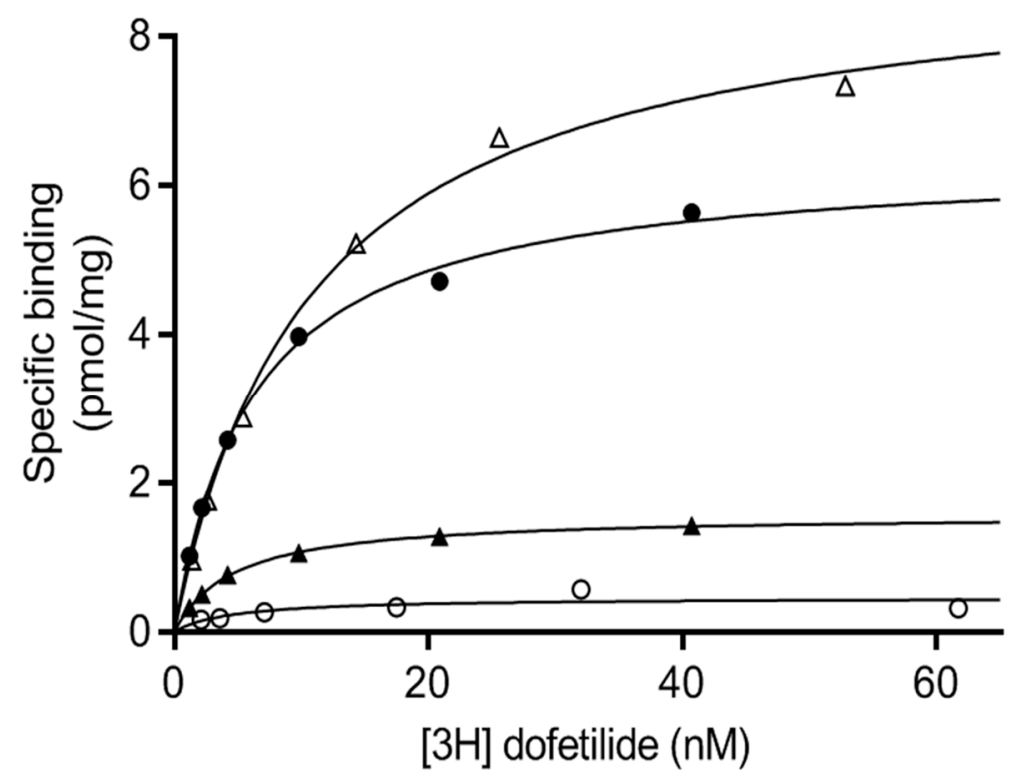

Figure 2. Characterization of the binding properties of $\left[{ }^{3} \mathrm{H}\right]$-dofetilide to hERG(S1-coil) expressed in three recombinant systems. The chimeric hERG(S1-coil) channel was expressed in the yeast P. pastoris, Sf9 insect and mammalian HEK293 cells (transient transfection and stable and inducible cell lines). Membranes were prepared for each system. Saturation ligand binding experiments with $\left[{ }^{3} \mathrm{H}\right]$ dofetilide were performed using $10 \mu \mathrm{g}$ of total membrane protein. Specific binding was calculated from total and non-specific measurements in triplicate (unspecific values are comprised between 0.5 and $1 \mathrm{pmol} / \mathrm{mg}$ ). All error bars are all less than $0.6 \mathrm{pmol} / \mathrm{mg}$. Empty triangles = P. pastoris; Filled circles = HEK stable; Filled triangles $=$ Sf9; Empty circles $=$ HEK transient.

Table 2. Binding values of $\left[{ }^{3} \mathrm{H}\right]$ dofetilide to hERG(S1-coil) expressed in 3 recombinant systems.

\begin{tabular}{|c|c|c|c|c|c|c|}
\hline & & Batch 1 & Batch 2 & Batch 3 & Batch 4 & Mean \\
\hline \multirow{2}{*}{$\begin{array}{c}\text { Yeast Pichia } \\
\text { pastoris }\end{array}$} & $\mathbf{B}_{\max }$ & $9.06+/-0.32$ & $14.99+/-0.41$ & & & $\begin{array}{c}12.03+/-0.37 \\
\mathrm{pmol} / \mathrm{mg}\end{array}$ \\
\hline & $K_{\mathrm{D}}$ & $10.77+/-1.08$ & $9.98+/-0.68$ & & & $10.38+/-0.90 \mathrm{nM}$ \\
\hline \multirow{2}{*}{ Insect cells Sf9 } & $\mathbf{B}_{\max }$ & $1.57+/-0.03$ & $0.50+/-0.04$ & $0.90+/-0.14$ & & $\begin{array}{c}0.99+/-0.09 \\
\mathrm{pmol} / \mathrm{mg}\end{array}$ \\
\hline & $K_{\mathbf{D}}$ & $4.56+/-0.30$ & $5.84+/-1.30$ & $35.37+/-9.69$ & & $15.29+/-6.92 \mathrm{nM}$ \\
\hline \multirow{2}{*}{$\begin{array}{l}\text { HEK293 } \\
\text { transient }\end{array}$} & $\mathbf{B}_{\max }$ & $0.46+/-0.01$ & $1.00+/-0.05$ & & & $\begin{array}{c}0.73+/-0.04 \\
\mathrm{pmol} / \mathrm{mg}\end{array}$ \\
\hline & $K_{\mathbf{D}}$ & $4.54+/-2.24$ & $7.53+/-1.00$ & & & $6.04+/-1.74 \mathrm{nM}$ \\
\hline \multirow{2}{*}{$\begin{array}{l}\text { HEK293 stable } \\
\text { and inducible }\end{array}$} & $\mathbf{B}_{\max }$ & $3.71+/-0.27$ & $6.36+/-0.14$ & $15.13+/-0.53$ & $6.07+/-0.38$ & $\begin{array}{c}7.82+/-0.36 \\
\mathrm{pmol} / \mathrm{mg}\end{array}$ \\
\hline & $K_{\mathbf{D}}$ & $7.33+/-1.46$ & $6.24+/-0.44$ & $25.90+/-2.20$ & $11.03+/-2.02$ & $12.38+/-1.68 \mathrm{nM}$ \\
\hline
\end{tabular}

Saturation ligand binding experiments with $\left[{ }^{3} \mathrm{H}\right]$ dofetilide were carried out on membranes from yeast Pichia pastoris, insect cells Sf9 or mammalian cells HEK293 (transient transfection or stable and inducible cell line). Each Bmax and $K_{D}$ values were calculated from triplicates of samples obtained from two to four batches of production in each recombinant system.

\subsection{Total Expression of hERG(S1-coil) in Different Cell Membranes}

The total production yields of hERG(S1-coil) were investigated by quantitative Western blot on membranes prepared from $P$. pastoris and stable HEK cells. For quantification after protocol optimization, $20 \mu \mathrm{g}$ of total membrane protein prepared from P. pastoris and $10 \mu \mathrm{g}$ of total membrane protein prepared from HEK cells were analysed by comparison with increasing quantities from 120 to $480 \mathrm{ng}$ of purified hERG(S1-coil) channel (Figure 3B). Thus, the signal intensity on Western blot is directly linked to the quantity of channel without discrimination of functional or non-functional, as 
we worked under denaturing conditions. Purified sample was obtained from P. pastoris membranes expressing hERG(S1-coil), solubilized in dodecylphosphocholine (DPC) and purified on TALON ${ }^{\circledR}$ resin. The purity of the purified protein was checked by SDS-PAGE (Figure 3A) and the protein concentration of the sample measured by BCA assay.

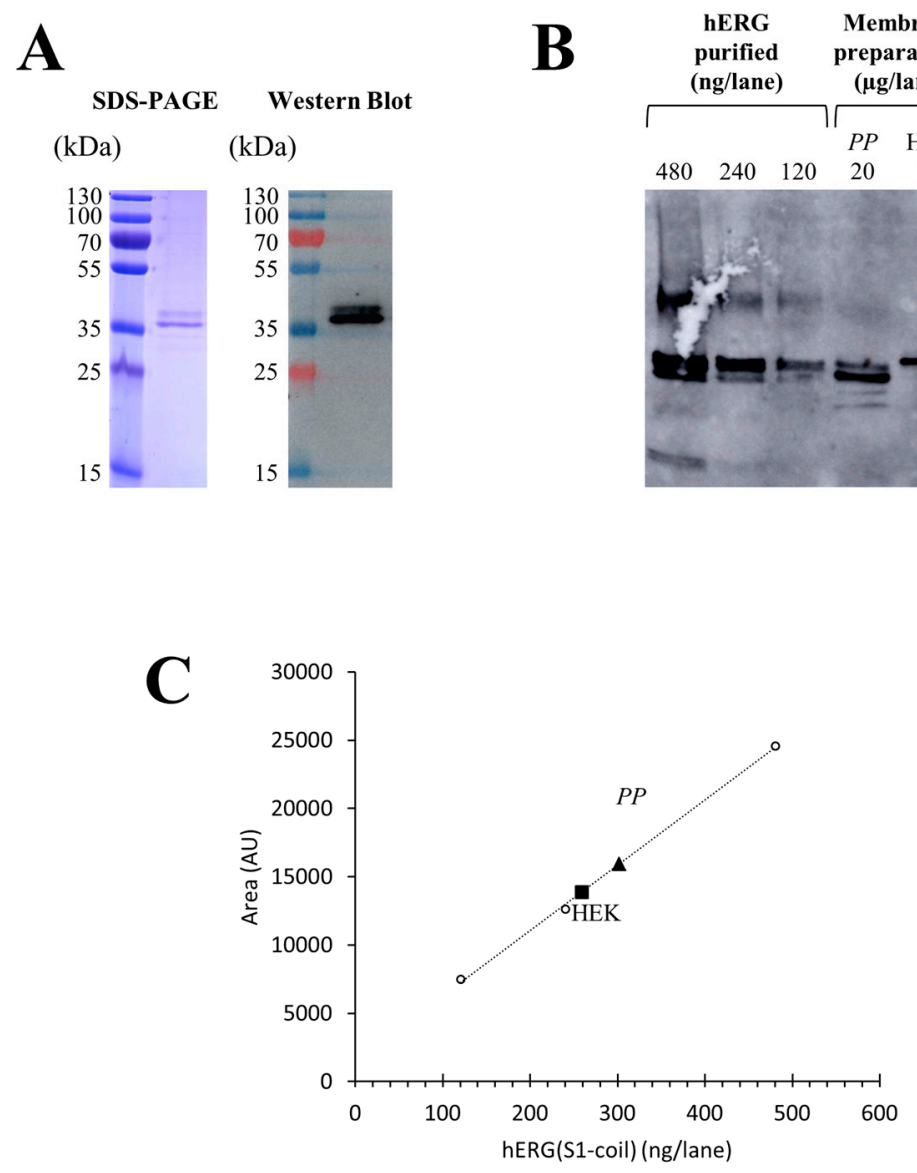

Figure 3. Quantification of hERG in P. pastoris and HEK membranes. A. hERG(S1-coil) expressed in P. pastoris was solubilized in $1 \%$ dodecylphosphocholine (DPC) and purified on a TALON ${ }^{\circledR}$ resin. The presence and purity of the protein was validated by SDS-PAGE (lane 1) and Western blot (lane 2). The purified protein was quantified by the BCA test. B. Increasing quantities of purified proteins and membrane preparations of P. pastoris and HEK were studied by Western blot using an anti-hERG antibody. C. hERG can be quantified in membranes of $P$. pastoris (triangle) and HEK (square) cells after fitting the linear equation between the amount of purified hERG(S1-coil) from A used as a standard and the fluorescent area on Western blot $\left(\mathrm{R}^{2}=0.9986\right)$.

Notably, expression of the non-mutated channel at the N-glycosylation site in P. pastoris resulted in a double band. In contrast, the channel mutated at N598 and produced in HEK cells resulted in a single band (Figure 3B). This typical feature of hERG has already been described in previous studies $[37,38]$. Regarding this experiment, the calculated amount of hERG(S1-coil) channel in P. pastoris was $15.1 \pm 3.7 \mu \mathrm{g} / \mathrm{mg}$ of total membrane proteins $(n=3)$ and $25.9 \pm 4.3 \mu \mathrm{g} / \mathrm{mg}$ of total proteins in HEK membranes $(n=3)$. In conclusion, stable HEK cells produce higher amounts of hERG(S1-coil) protein than P. pastoris based on the analysis of total expression and without discrimination of functionality.

\subsection{Deduction of the Percent of Activity in Membranes}

Finally, we wanted to quantify folded and misfolded protein in membranes by comparing the total quantity of proteins in Western blot with the amounts of functional channel in binding assays. The percent of activity was defined as the ratio between functional and total channel in membranes. 
Approximately $10 \%$ of the channels in P. pastoris membranes and $5 \%$ in stable HEK cells membranes were in a functional state (Table 3). The percent of functional channels in membranes from stable HEK cells was lower due to a higher level of total channel production compared to membranes from $P$. pastoris. Conversely, with a smaller total amount of channels and a higher amount of functional channels, P. pastoris afforded the best balance between the expression of receptors and the number of functional receptors. Thus, considering our goal of producing large amounts of active hERG(S1-coil) and evaluating the functional part of the protein in the total production, $P$. pastoris seems to be the best recombinant system.

Table 3. Quantification of hERG functionality in P. pastoris and HEK membranes.

\begin{tabular}{|c|c|c|c|}
\hline & P. pastoris & Stable and Inducible HEK & \\
\hline \multicolumn{4}{|c|}{ Functional hERG in membranes } \\
\hline Method of quantification & \multicolumn{2}{|c|}{ Radioligand binding assay } & \\
\hline $\begin{array}{l}\text { Channel concentration in } \\
\text { crude membranes }\end{array}$ & 9.06 & 6.36 & $\begin{array}{l}\mathrm{pmol} / \mathrm{mg} \text { of protein in } \\
\text { membranes }\end{array}$ \\
\hline $\begin{array}{l}\text { Molecular weight of the } \\
\text { tetrameric channel }\end{array}$ & 168,099 & 185,555 & $\mathrm{~g} / \mathrm{mol}$ \\
\hline $\begin{array}{l}\text { Channel concentration } \\
\text { in crude membranes }\end{array}$ & 1.52 & 1.18 & $\begin{array}{l}\mu \mathrm{g} / \mathrm{mg} \text { of protein in } \\
\text { membranes }\end{array}$ \\
\hline \multicolumn{4}{|c|}{ Total hERG in membranes } \\
\hline Method of quantification & \multicolumn{2}{|c|}{ Western blot } & \\
\hline $\begin{array}{l}\text { Quantity of channel on } \\
\text { Western blot }\end{array}$ & 301.79 & 258.63 & ng/lane \\
\hline $\begin{array}{c}\text { Quantity of total protein } \\
\text { on Western blot }\end{array}$ & 20 & 10 & $\mu \mathrm{g} / \mathrm{lane}$ \\
\hline $\begin{array}{l}\text { Channel concentration } \\
\text { in crude membranes }\end{array}$ & 15.09 & 25.86 & $\begin{array}{l}\mu \mathrm{g} / \mathrm{mg} \text { of protein in } \\
\text { membranes }\end{array}$ \\
\hline \multicolumn{4}{|c|}{ Percentage of functional channel in membranes } \\
\hline Functional/Total & $10 \%$ & $5 \%$ & \\
\hline
\end{tabular}

\subsection{Solubilization of $h E R G(S 1-c o i l)$ in Non-Ionic and Zwitterionic Detergents}

After production of a membrane protein, another challenging step is membrane extraction to individualize the protein before purification. The critical point is to get the protein out of its lipid environment while maintaining a native conformational state [39]. Thus, detergents have been widely used for decades to solubilize membrane proteins; they have the ability to substitute lipids around the hydrophobic domains of the protein via micelle arrangement [40]. Detergents are classified into three main classes: non-ionic, zwitterionic and ionic. Ionic detergents, including sodium dodecyl-sulphate (SDS), have a denaturing effect on membrane proteins by disrupting both inter- and intra-molecular protein-protein interactions [41]. For this reason, we did not use this class of molecules. Zwitterionic detergents are softer because of their neutral global charge. For example, Fos-choline-14 was recently shown to be the most suitable detergent for solubilizing the Kir6.2 potassium channel by maintaining the native tetrameric structure [42]. Nevertheless, these molecules, including DPC, can often disrupt protein-protein interactions. The non-ionic detergents, including dodecylmaltoside (DDM), are a non-denaturing group of molecules that only disrupt protein-lipid and lipid-lipid interactions. In the literature, most of the membrane proteins are extracted and purified in non-ionic detergents, such as DDM [43].

After production in three recombinant systems, the potency of two detergents for extracting hERG(S1-coil) from membranes of P. pastoris, Sf9 and stable HEK cells was evaluated. Both the non-ionic detergent DDM and zwitterionic detergent DPC were tested. Results are given in Figure 4. Interestingly, we found that hERG(S1-coil) expressed in three recombinant systems had different 
solubilization properties. Though hERG(S1-coil) produced in HEK cells can be solubilized in both zwitterionic and non-ionic detergents, the channel produced in P. pastoris or Sf9 cells is only solubilized in the harsh detergent DPC but not in the soft detergent DDM. This differential behaviour is likely to be related to lipid variations in the membrane composition between the three cell hosts. Regarding the solubilization with DDM, that more likely preserves the tetrameric organization of the channel, stable HEK cells could be a better strategy for production, from which the protein could be functionally extracted by DDM, despite the percent of functional channels being lower than P. pastoris.

Pichia pastoris

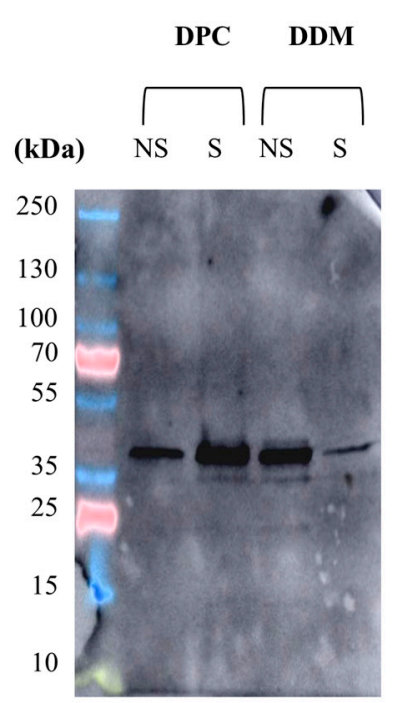

Sf9

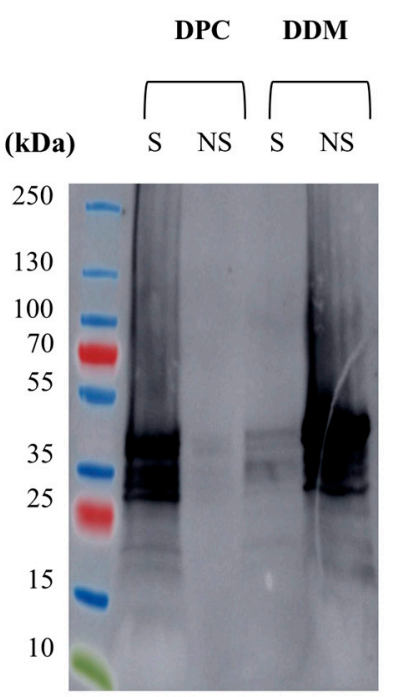

HEK

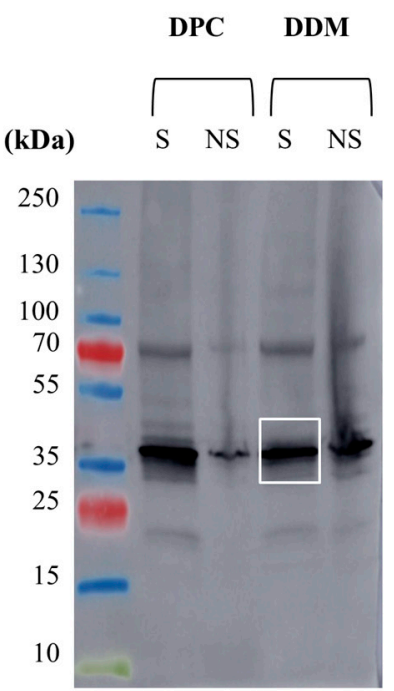

Figure 4. Detergent extraction of hERG from the membranes of three recombinant systems. Membranes were prepared from yeast $P$. pastoris, Sf9 insect cells or stable mammalian HEK cells expressing hERG(S1-coil). A sample of each membrane containing $20 \mu \mathrm{g}$ of total protein for P. pastoris and HEK cells or $1000 \mu \mathrm{g}$ of protein for Sf9 cells was incubated with 1\% dodecylmaltoside (DDM) or $1 \%$ DPC. Solubilized (S) and non-solubilized (NS) fractions were studied by Western blot with an anti-His antibody.

\subsection{Channel Function after Extraction with Detergent}

Thus, to investigate the channel function after membrane extraction in detergent, we purified the protein from P. pastoris, Sf9 or stable HEK membranes and integrated the purified channel into reconstituted bilayer membranes to record currents. We wanted to determine whether previous solubilization in non-ionic (DDM) or zwitterionic (DPC) detergents interferes with the native conformation and function of the channel. The differences between DDM and DPC in terms of their extraction potency and the resulting solubilized protein functionality is a common observation that has already been reported (see Chipot et al. [44] for a review). As illustrated in Figure 5A, in the case of HEK membranes solubilized and purified in DDM, the hERG(S1-coil) channel was able to open after depolarization at a negative potential of $-100 \mathrm{mV}$. In addition, both single and multiple-channel activities were only observed at negative potentials. 


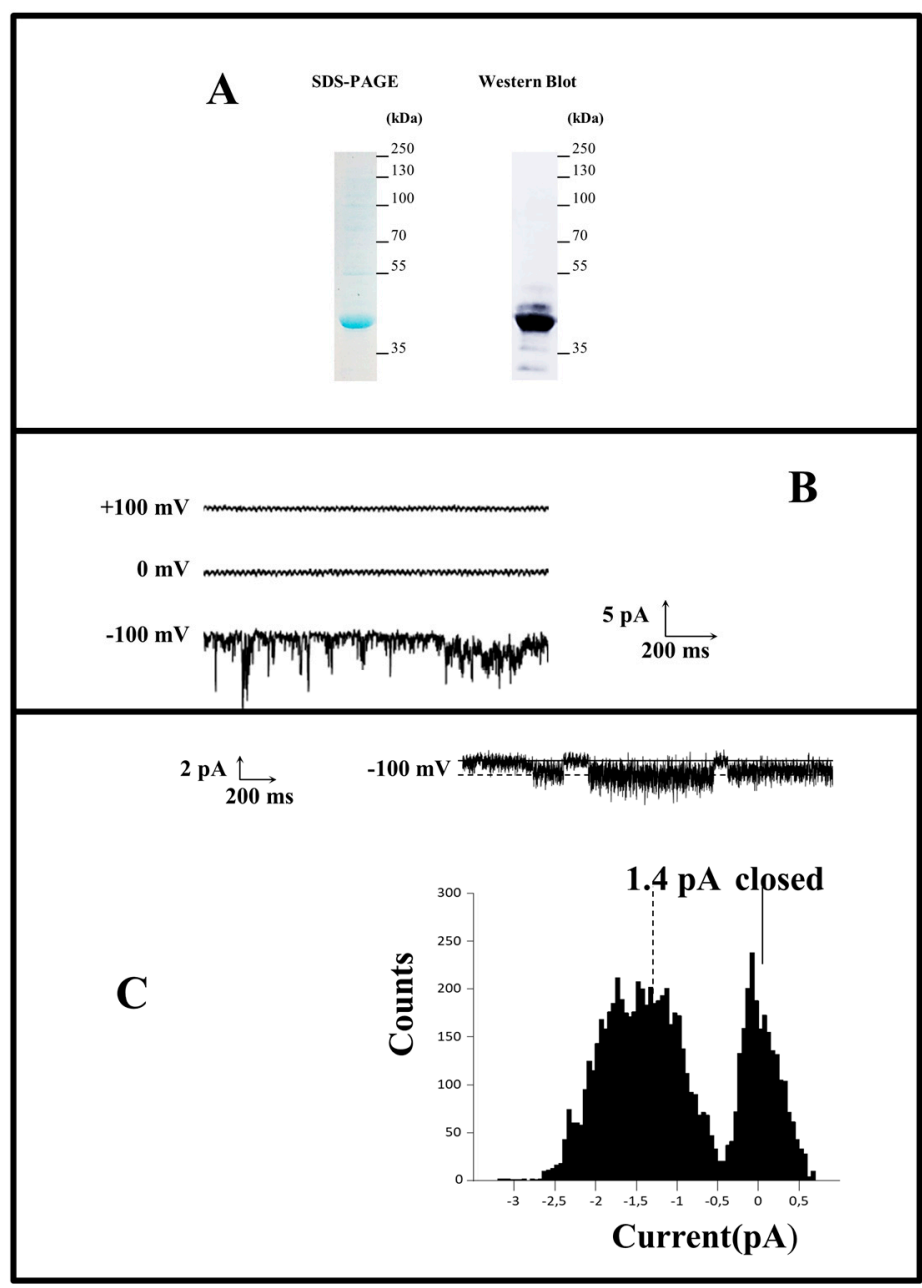

Figure 5. hERG channel function in lipid bilayers after HEK expression and DDM solubilization. A. The purified hERG(S1-coil) was overexpressed in stable HEK cell line, solubilized in 1\% DDM and the resulting supernatant was purified on a Strep affinity resin and eluted with $2 \mathrm{mM}$ biotin. B. hERG(S1-coil) multichannel currents recorded at an applied potential of $+100,0$ and $-100 \mathrm{mV}$. B. Single hERG(S1-coil) channel currents recorded at an applied potential of $-100 \mathrm{mV}$. C. Current trace and related point-amplitude histogram.

As reported in the literature, no outward currents were observed at positive voltages [45]. Moreover, samples pre-incubated with $10 \mu \mathrm{M}$ of BeKm-1 toxin did not have any current at $-100 \mathrm{mV}$ (data not shown). This confirms the identity of the ionic channel recorded in this experiment. By focusing on hERG(S1-coil), single-channel stepwise currents were recorded with an average of $1.4 \mathrm{pA}$ (Figure 5B). These data are in agreement with hERG-wt current records in the literature [46]. In contrast, when hERG(S1-coil) channels from P. pastoris and Sf9 membranes solubilized in DPC were integrated into bilayer membranes, no electrophysiological activity was detected (data not shown). These results demonstrate that the channel is in an activated-open state after extraction in DDM but seems to be mostly non-functional after extraction in DPC. This result is in agreement with our hypothesis and confirms that it is preferable to produce hERG(S1-coil) in stable HEK cells to allow membrane solubilization in DDM and then purify a functional channel for structural and/or biophysical characterization.

\section{Conclusions}

Access to fair amounts of integral membrane proteins is imperative in modern pharmacology research. Thus, different accessible systems susceptible to producing a functional protein were 
tested. Because of the absence of expression in E. coli, this system has been early abandoned. Then, expression in Sf9 showed really poor expression of functional protein. Interestingly, we found that the mutated/truncated hERG protein was expressed in the largest amount in the P. pastoris system in a functional state. But conversely, no extraction with the smooth detergent DDM was possible with this recombinant system and extraction with the harsh detergent DPC resulted in a non-functional channel. In contrast, lower amounts of hERG channel were produced with the stable and inducible HEK cell line but the possibility of extraction with DDM offered a functional purified channel. In addition, we demonstrated that the generation of a cell line is a way to significantly increase the amount of expression of the protein of interest compared to transient expression in HEK cells. We were able to purify approximately $100 \mu \mathrm{g}$ of the channel from $1 \mathrm{~L}$ of culture from our cell line ( $2.10^{8}$ cells). Thus, we grossly estimate that approximately $15 \mathrm{~L}$ of HEK culture (roughly $5.10^{9}$ cells) should be necessary to prepare a batch of $1 \mathrm{mg}$ of purified hERG(S1-coil). This study illustrates difficulties commonly met for heterologous expression of a membrane protein. The balance between growing quantities and maintaining the activity (avoiding misfolding and aggregation) needs to be finely controlled and dictates the selection of one host over the other. In this context, this new approach paves the way for gaining information on structure and the biophysical interactions between any ligands and the purified channel. Although recent studies provide new elements on hERG function and structure, several questions are still unanswered to understand the mechanisms of drug binding.

In summary, hERG was highly expressed in P. pastoris but solubilization led to a dead channel; there was no expression in E. coli while expression in mammalian cells (HEK cells), even if at relatively low level, led to a functional purified channel.

\section{Materials and Methods}

\subsection{Materials}

Astemizole was purchased from Sigma Aldrich (Saint-Quentin Fallavier, France), E-4031 from Cayman Chemical (Ann Arbor, MI, USA), recombinant toxin BeKm-1 and anti-hERG(extracellular) antibody from Alomone (Jerusalem, Israel) and $\left[{ }^{3} \mathrm{H}\right]$-dofetilide from Perkin Elmer (Roissy-en-France, France). Detergents n-dodecyl- $\beta$-D-maltopyranoside (DDM) and n-dodecylphosphocholine (DPC) were ordered from Anatrace (Maumee, OH, USA). FreeStyle ${ }^{\mathrm{TM}} 293-\mathrm{F}$ cells were purchased from ThermoFisher Scientific (Villebon, France). A stable FreeStyle ${ }^{\mathrm{TM}}$ 293-F cell line expressing hERG(S1-coil) after doxycycline induction was also ordered from Vectalys (Toulouse, France).

\subsection{Molecular Biology}

The hERG full-length sequence in pcDNA3.1 plasmid was provided by Dr. Thierry Cens from IBMM (Montpellier, France). A second plasmid, pEX-A2, containing the coiled-coil sequence was ordered from Eurofins Genomics. As described by Hausammann and Grütter [25], the truncated hERG sequence from amino acids 362 to 675 was cloned by PCR using the following primers: forward F1, CATGAAGATAAAGGAGCGAACCCAC; and reverse R1, CATCCTGGAACCAGATCCGCCTGTGTGGTATCGGGCTGTGC. The coiled-coil sequence was cloned using the following primers: forward F2, GCACAGCCCGCTACCACACAGGCGGATCTGGTTCCAGGATG; and reverse R2, CTATCTTTCCCCTAACAACTTCTTTATGC. Both were linked by overlapping PCR using oligonucleotides F1 and R2. The chimeric construct was checked by sequencing. For expression in Xenopuslaevis oocytes, the hERG(S1-coil) sequence was subcloned into a pCMV-PL10 vector, with the Alfalfa Mosaic Virus (AMV) sequence immediately before the start codon and the 3'-UTR sequence of the X. laevis -globin gene immediately after the stop codon. Capped cRNA transcripts coding for hERG(S1-coil) were obtained from linearized plasmid using the mMessagemMachine $\mathrm{T} 7$ transcription kit (Thermo Fisher), following the manufacturer's instructions. The concentrations were adjusted to $1 \mu \mathrm{g} / \mu \mathrm{L}$. For high level production in different recombinant systems, optimized sequences were 
ordered from GeneCust (Ellange, Luxembourg). Selected plasmids and additional tags are referenced in Table 1.

\subsection{Electrophysiology in Xenopus Oocytes}

Stage V-VI oocytes were removed from female Xenopus under tricaine anaesthesia. Oocytes were defolliculated by treatment with $1 \mathrm{mg} / \mathrm{mL}$ collagenase type 1A (Sigma Aldrich) under agitation at room temperature in OR2 solution ( $82.5 \mathrm{mM} \mathrm{NaCl}, 2 \mathrm{mM} \mathrm{KCl}, 1 \mathrm{mM} \mathrm{MgCl} 2,5 \mathrm{mM}$ HEPES, pH 7.2). After intensive washing with OR2 solution, oocytes were injected with RNA preparation (about $30 \mathrm{~nL}$ per oocyte) and recorded 2-5 days after injection. Currents were recorded at room temperature using the two-electrode voltage clamp method. Electrodes were pulled from borosilicate glass and filled with $3 \mathrm{M} \mathrm{KCl}$. Currents were measured by a Geneclamp 500 amplifier (Molecular Devices, San Jose, CA, USA) and digitized by a Digidata 1200 converter (Molecular Devices) using Clampex 5 software (Molecular Devices). Oocytes were clamped at $-80 \mathrm{mV}$ and leak currents subtracted online using a $\mathrm{P} / 3$ protocol of hyperpolarizing pre-pulses. The external solution, ND-hERG, has the following composition: $96 \mathrm{mM} \mathrm{NaCl}, 3 \mathrm{mM} \mathrm{KCl}, 0.5 \mathrm{mM} \mathrm{CaCl}_{2}, 1 \mathrm{mM} \mathrm{MgCl}_{2}, 5 \mathrm{mM}$ HEPES, pH 7.4. Inhibitors were diluted in ND-hERG solution and superfused through the recording chamber at a rate of $1 \mathrm{~mL} / \mathrm{min}$ with increasing concentrations: from $100 \mathrm{pM}$ to $200 \mathrm{nM}$ for BeKm-1 and from $1 \mathrm{nM}$ to $50 \mu \mathrm{M}$ for E-4031. Currents were elicited by a two-step depolarization protocol from a holding potential of $-80 \mathrm{mV}$ with voltages ranging from -70 to $-30 \mathrm{mV}$ in $10 \mathrm{mV}$ increment during $4 \mathrm{~s}$ and then back to $-50 \mathrm{mV}$ for $2 \mathrm{~s}$. We determined the concentration to obtain the half maximal inhibition $\left(\mathrm{IC}_{50}\right)$ by measuring the peak tail current recorded during the second pulse at $-50 \mathrm{mV}$ in the presence of increasing concentrations of inhibitor and normalized the value to the current measured in the absence of inhibitor. Curves were fitted with a logistic function (Prism, GraphPad). Data are represented as mean \pm SEM of $n$ oocytes. The significance of the difference between two results was determined using the unpaired Student's test set at the 0.01 level.

\subsection{Production in P. pastoris}

The hERG(S1-coil) sequence was subcloned into a pPIC9K vector with a 10-histidine tag at the $3^{\prime}$ end of the construct. P. pastoris SMD1163 cells were transformed with the plasmid. Selection for His+ transformants was carried out by Yeastern Blot [29]. One clone was selected for further study. A single colony was grown overnight in BMGY $(1 \%(w / v)$ yeast extract, $2 \%(w / v)$ peptone, $1.34 \%(w / v)$ yeast nitrogen base without amino acids, $1 \%(w / v)$ glycerol and $0.1 \mathrm{M}$ phosphate buffer, $\mathrm{pH} 6.0$ at $30{ }^{\circ} \mathrm{C}$ with shaking at $250 \mathrm{rpm}$ until an optical density at $600 \mathrm{~nm}\left(\mathrm{OD}_{600}\right)$ between 4 and 5 (arbitrary units). The hERG(S1-coil) expression was induced at $+22^{\circ} \mathrm{C}$ for $20 \mathrm{~h}$ in BMMY medium $1 \%(w / v)$ yeast extract, $2 \%(w / v)$ peptone, $1.34 \%(w / v)$ yeast nitrogen base without amino acids, $0.5 \%(v / v)$ methanol and $0.1 \mathrm{M}$ phosphate buffer, $\mathrm{pH}$ 6.0) containing 2.5\% dimethylsulfoxide (DMSO). Cells were harvested by centrifugation and stored at $-80^{\circ} \mathrm{C}$ until purification.

\subsection{Production in Sfg Insect Cells}

The hERG(S1-coil) sequence optimized for expression in insect cells was subcloned into pFB1. A double-streptavidin tag and $3 C$ cleavage site were added at the $5^{\prime}$ end of the construct and a TEV (Tobacco Etch Virus) cleavage site and 6-histidine tag added at the $3^{\prime}$ extremity (Table 1). Following the Bac-to-Bac ${ }^{\mathrm{TM}}$ method (Invitrogen, Life Technologies, ThermoFischer Scientific), the recombinant vector was transferred to competent $E$. coli $\mathrm{DH} 10 \mathrm{Bac}$ cells to produce recombinant bacmid by homologous recombination. Viral stock was obtained by transfection of Sf9 cells with the recombinant bacmid. Finally, a culture of Sf 9 insect cells at a density of $4 \times 10^{6}$ cells $/ \mathrm{mL}$ in suspension in EX-CELL ${ }^{\circledR} 420$ Serum-Free medium (SigmaAldrich) was infected by the viral stock encoding hERG(S1-coil) at a concentration of $1: 500(v / v)$ for $48 \mathrm{~h}$ at $28^{\circ} \mathrm{C}$ with shaking. Cells were harvested by centrifugation and stored at $-80^{\circ} \mathrm{C}$ until purification. 


\subsection{Production in HEK Cells}

For transient production, the synthetic gene corresponding to hERG(S1-coil) was integrated into a pCI-neo plasmid containing a TEV cleavage site, streptavidin binding peptide (SBP) tag and 6-histidine tag at the $3^{\prime}$ end of the chimeric construct. A mutation was inserted by replacing asparagine $(\mathrm{N})$ at position 598 of the hERG amino acid sequence with a glutamine (Q). FreeStyle ${ }^{\mathrm{TM}}$ 293-F cells were transfected by electroporation. The stable cell line was generated by lentiviral transduction of HEK293FS EF1-tTS+EF1-TetOn3G-IRES-Neo with a lentivirus, rLV.TRE3G, containing hERG(S1-coil) with a TEV cleavage site, SBP tag and 6-histidine tag at the $3^{\prime}$ end of the chimera construct. An N598Q mutation was also inserted. After clonal selection, cells were cultivated in Freestyle 293 media (Gibco, ThermoFisher Scientific) complemented with 1\% H-T supplement (Gibco) and $0.25 \%$ penicillin-streptomycin. For production, cells were seeded at 200,000 cells $/ \mathrm{mL}$ and incubated at $+37^{\circ} \mathrm{C}$ in $8 \% \mathrm{CO}_{2}$ at $125 \mathrm{rpm}$. Production of the protein of interest was induced with $10 \mathrm{ng} / \mathrm{mL}$ doxycycline. After $24 \mathrm{~h}$ of incubation, cells were pelleted by centrifugation.

\subsection{Preparation of Crude Membranes}

For membrane preparation of yeast, pellets were resuspended in a lysis buffer containing $50 \mathrm{mM}$ Tris, $\mathrm{pH} 7.4,500 \mathrm{mM} \mathrm{NaCl}, 10 \%$ glycerol, $1 \mathrm{mM}$ ethylenediaminetetraacetic (EDTA) and $1 \mathrm{mM}$ phenylmethylsulfonyl fluoride (PMSF). Glass beads ( $0.5 \mathrm{~mm}$; SigmaAldrich) were added to the mixture. Cell lysis was carried out using FastPrep 24 (MP Biomedicals, Illkirch, France) with alternating stirring and cooling cycles followed by $5 \mathrm{~min}$ of centrifugation at $5000 \mathrm{~g}$ and $+4{ }^{\circ} \mathrm{C}$. The supernatant was then ultracentrifuged at 100,000 $\mathrm{g}$ for $30 \mathrm{~min}$ at $+4{ }^{\circ} \mathrm{C}$. The pellet was resuspended in membrane buffer (50 mM Tris, pH 7.4, $500 \mathrm{mM} \mathrm{NaCl}, 10 \%$ glycerol). For insect and mammalian cells, the following protocol was carried out to prepare membranes. Cellular pellets were suspended in lysis buffer containing 10 mM HEPES (pH7.4), 1 mM EDTA and 1 mM PMSF using a Dounce homogenizer. The mixture was centrifuged for $10 \mathrm{~min}$ at $1000 \mathrm{~g}$ and $+4{ }^{\circ} \mathrm{C}$. The supernatant was then ultracentrifuged at 100,000 $\mathrm{g}$ for $30 \mathrm{~min}$ at $+4{ }^{\circ} \mathrm{C}$. The pellet was resuspended in membrane buffer (50 mM HEPES, $\mathrm{pH} 7.4,120 \mathrm{mM} \mathrm{NaCl}, 10 \%$ glycerol) with a ratio of $1 \mathrm{~mL}$ of membrane buffer for $1.5 \times 10^{8}$ cells. After crude membrane preparation and for each production system, a BCA protein assay (Thermo Fisher) was performed following the manufacturer's instructions.

\subsection{Radiolabeled Ligand Binding Assay}

Crude membranes were used to assess the capability of recombinant hERG(S1-coil) to bind one of its ligands, dofetilide. Aliquots of $10 \mu \mathrm{g}$ of total membrane proteins in a total volume of $100 \mu \mathrm{L}$ of incubation buffer (10 mM HEPES, pH 7.5, $130 \mathrm{mM} \mathrm{NaCl}, 60 \mathrm{mM} \mathrm{KCl}, 0.8 \mathrm{mM} \mathrm{MgCl} 2,1 \mathrm{mM} \mathrm{NaEGTA}$, $10 \mathrm{mM}$ glucose, $0.1 \% \mathrm{BSA}$ ) were mixed with $\left[{ }^{3} \mathrm{H}\right]$-dofetilide at concentrations ranging from $1 \mathrm{nM}$ to $40 \mathrm{nM}$. Non-specific binding was determined in the presence of $10 \mu \mathrm{M}$ of astemizole [47]. After $2 \mathrm{~h}$ of incubation at room temperature, the mixtures were filtered on 96-well Unifilter GF/B plates pre-soaked in poly-ethyleneimine (PEI) and washed six times with $1 \mathrm{~mL}$ ice cold wash buffer $(10 \mathrm{mM}$ Tris-HCl, pH 7.4, $130 \mathrm{mM} \mathrm{NaCl}, 5 \mathrm{mM} \mathrm{KCl}, 0.8 \mathrm{mM} \mathrm{CaCl}_{2}, 0.1 \%$ BSA). Filter-bound ligand was counted using a TopCount (Perkin Elmer) scintillation counter. Total binding and non-specific binding were determined with these measures and specific binding deduced. A resulting graph was drawn with Prism (v8, GraphPad, San Diego, CA, USA) using the Sigmaplot non-linear regression tool, ligand binding and one site saturation $\left(\mathrm{f}=\mathrm{B}_{\max } \mathrm{x} \operatorname{abs}(\mathrm{x}) /\left(\mathrm{K}_{\mathrm{d}}+\mathrm{abs}(\mathrm{x})\right)\right)$ to estimate binding affinity $\left(\mathrm{K}_{\mathrm{d}}\right)$ and capacity $\left(\mathrm{B}_{\max }\right)$.

\subsection{Protein Quantification by Western Blot}

To quantify total protein produced in P. pastoris and HEK membranes, a sample corresponding to 10 or $20 \mu \mathrm{g}$ of total protein were analysed by polyacrylamide gel electrophoresis and transferred onto a nitrocellulose membrane. hERG(S1-coil) was specifically labelled with an anti-hERG extracellular 
primary antibody at a dilution of 1:500 (v:v) followed by a secondary fluorescent anti-rabbit-HRP antibody (Sigma Aldrich).

A range of concentrations with purified hERG(S1-coil) at known concentration determined by the BCA assay were also deposited on gel. The hERG(S1-coil) concentration in membrane samples was calculated using ImageJ (https://imagej.nih.gov/ij/) after determination of the relationship between hERG(S1-coil) concentration and band intensity on Western blot.

\subsection{Protein Solubilization and Purification}

Crude membranes prepared from P. pastoris, Sf9 or stable HEK cells expressing hERG(S1-coil) were solubilized in $50 \mathrm{mM}$ HEPES, $\mathrm{pH} 7.5,300 \mathrm{mM} \mathrm{KCl}$ containing $1 \%$ DPC or DDM and $0.2 \%$ cholesteryl-hemisuccinate (CHS, Sigma Aldrich) at slow rotation at $+4{ }^{\circ} \mathrm{C}$ for $1 \mathrm{~h}$. Samples were centrifuged at 25,000 $\mathrm{g}$ for $15 \mathrm{~min}$ at $+4{ }^{\circ} \mathrm{C}$. For the purification of hERG(S1-coil) overexpressed in P. pastoris in DPC, the supernatant was incubated with $\mathrm{Co}^{++}$affinity resin (TALON ${ }^{\circledR}$ Metal Affinity Resin, Clontech, Saint-Germain-en-Laye, France) at a ratio of $1 \mathrm{~mL}$ resin for $30 \mathrm{~mL}$ of supernatant with $20 \mathrm{mM}$ imidazole at slow rotation at $+4{ }^{\circ} \mathrm{C}$ for $1 \mathrm{~h}$. After transferring to a column and washing the resin with $15 \mathrm{CV}$ of $50 \mathrm{mM}$ HEPES, $\mathrm{pH} 7.5,300 \mathrm{mM} \mathrm{KCl}, 50 \mathrm{mM}$ imidazole, $0.1 \%(w / v)$ DPC and $0.02 \%$ $(w / v)$ CHS, hERG(S1-coil) was eluted with $250 \mathrm{mM}$ imidazole in the same buffer. For purification of hERG(S1-coil) overexpressed in Sf9 cells in DPC, the supernatant was diluted 2-fold in 50 mM HEPES, pH 7.5 and transferred to a Strep-Tactin column (Strep-TactinSuperflow, IBA, Göttingen, Germany) at a ratio of $1 \mathrm{~mL}$ resin for $100 \mathrm{~mL}$ supernatant. The resin was washed with $15 \mathrm{CV}$ of $50 \mathrm{mM}$ HEPES, $\mathrm{pH} 7.5,300 \mathrm{mM} \mathrm{KCl}, 0.1 \%(w / v)$ DPC and $0.02 \%(w / v)$ CHS and elution was performed by the addition of $2.5 \mathrm{mM}$ D-desthiobiotin (IBA) in the same buffer. Purification of hERG(S1-coil) overexpressed in stable HEK cells was carried out in DDM. The supernatant was diluted 2-fold in 50 mM HEPES, pH 7.5 and transferred to a column with streptavidin resin (High Capacity Streptavidin Agarose Resin, Life Technologies, Thermo Fischer Scientific) at a ratio of $1 \mathrm{~mL}$ resin for $100 \mathrm{~mL}$ supernatant. The resin was washed with $15 \mathrm{CV}$ of $50 \mathrm{mM}$ HEPES, pH 7.5, $300 \mathrm{mM} \mathrm{KCl}, 0.1 \%(w / v)$ DDM and $0.02 \%(w / v) \mathrm{CHS}$ and elution was performed by the addition of $2 \mathrm{mM}$ biotin (Sigma) in the same buffer. Purified samples were analysed by SDS-PAGE and Western blot and protein concentrations determined by BCA assay.

\subsection{Electrophysiology on Lipid Bilayers}

Planar lipid bilayers were formed at room temperature by painting a solution of azolectin (Type IVS, Sigma Aldrich) at $45 \mathrm{mg} / \mathrm{mL}$ in decane across a $200 \mu \mathrm{m}$ aperture in a polysulfonate cup (Warner Instruments, Hamden, CT, USA) separating two chambers. The trans chamber compartment was connected to the headstage input of a bilayer voltage clamp amplifier (BC-525D, Warner Instruments). The cis chamber was held at virtual ground. Voltages were applied to the planar lipid bilayers through $\mathrm{Ag}-\mathrm{AgCl}$ electrodes connected to the chambers via agar/KCl bridges. The solution in both chambers was $120 \mathrm{mM} \mathrm{KCl}$ in $10 \mathrm{mM}$ HEPES, pH 7.3. A total of $500 \mathrm{ng}$ of chimeric hERG protein was added in the cis chamber and the resulting channel activity recorded for at least $2 \mathrm{~min}$. For analysis, the data were filtered to $1 \mathrm{kHz}$, digitized at $4 \mathrm{kHz}$ and collected on a Pentium computer using Axoxcope10 and Digidata 1440A (Molecular Devices, San José, CA, USA).

Supplementary Materials: The following are available online at http://www.mdpi.com/1422-0067/20/13/3181/s1.

Author Contributions: L.V., R.W., A.C., G.F. and J.A.B. conceived and designed the experiments; L.V., T.C., N.S., V.K., C.O. and C.D. performed the experiments; L.V., T.C., R.W. and A.C. analysed the data; L.C., R.W. and J.A.B. wrote the paper.

Funding: This research received no external funding.

Acknowledgments: The authors wish to thank Sébastien Granier and Pascal Rochaix (IGF, Montpellier, France) for their help with the Sf9 system.

Conflicts of Interest: The authors declare no conflict of interest. 


\section{References}

1. Liu, J.; Rost, B. Comparing function and structure between entire proteomes. Prot. Sci. 2001, 10, 1970-1979. [CrossRef] [PubMed]

2. Cellular gatekeepers. Nat. Struct. Mol. Biol. 2016, 23, 463. [CrossRef] [PubMed]

3. Wallin, E.; von Heijne, G. Genome-wide analysis of integral membrane proteins from eubacterial, archaean and eukaryotic organisms. Prot. Sci. 1998, 7, 1029-1038. [CrossRef] [PubMed]

4. Overington, J.P.; Al-Lazikani, B.; Hopkins, A.L. How many drug targets are there? Nat. Rev. Drug Discov. 2006, 5, 993-996. [CrossRef] [PubMed]

5. Deisenhofer, J.; Epp, O.; Miki, K.; Huber, R.; Michel, H. Structure of the protein subunits in the photosynthetic

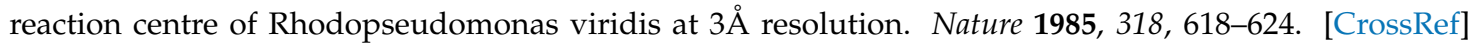
[PubMed]

6. Hendrickson, W.A. Atomic-level analysis of membrane-protein structure. Nat. Struct. Mol. Biol. 2016, 23, 464-467. [CrossRef] [PubMed]

7. Vénien-Bryan, C.; Li, Z.; Vuillard, L.; Boutin, J.A. Cryo-electron microscopy and X-ray crystallography. Complementary approaches to structural biology and drug discovery. Acta Crystallogr. F Struct. Biol. Commun. 2017, 73, 174-183. [CrossRef] [PubMed]

8. Renaud, J.-P.; Chung, C.W.; Danielson, U.H.; Egner, U.; Hennig, M.; Hubbard, R.E.; Nar, H. Biophysics in drug discovery. Impact, challenges and opportunities. Nat. Rev. Drug Discov. 2016, 15, 679-698. [CrossRef] [PubMed]

9. Igonet, S.; Raingeval, C.; Cecon, E.; Pučić-Baković, M.; Lauc, G.; Cala, O.; Baranowski, M.; Perez, J.; Jockers, R.; Krimm, I.; et al. Enabling STD-NMR fragment screening using stabilized native GPCR. A case study of adenosine receptor. Sci. Rep. 2018, 8, 8142. [CrossRef] [PubMed]

10. Rosano, G.L.; Ceccarelli, E.A. Recombinant protein expression in Escherichia coli. Advances and challenges. Front. Microbiol. 2014, 5, 172. [CrossRef] [PubMed]

11. Wagner, S.; Bader, M.L.; Drew, D.; de Gier, J.-W. Rationalizing membrane protein overexpression. Trends Biotechnol. 2006, 24, 364-371. [CrossRef] [PubMed]

12. Edwards, A.M.; Arrowsmith, C.H.; Christendat, D.; Dharamsi, A.; Friesen, J.D.; Greenblatt, J.F.; Vedadi, M. Protein production. Feeding the crystallographers and NMR spectroscopists. Nat. Struct. Biol. 2000, 7, 970-972. [CrossRef]

13. Logez, C.; Berger, S.; Legros, C.; Baneres, J.-L.; Cohen, W.; Delagrange, P.; Nosjean, O.; Boutin, J.A.; Ferry, G.; Simonin, F; et al. Recombinant human melatonin receptor MT1 isolated in mixed detergents shows pharmacology similar to that in mammalian cell membranes. PLoS ONE 2014, 9, e100616. [CrossRef] [PubMed]

14. Logez, C.; Damian, M.; Legros, C.; Dupre, C.; Guery, M.; Mary, S.; Wagner, R.; M'Kadmi, C.; Nosjean, O.; Fould, B.; et al. Detergent-free Isolation of Functional G Protein-Coupled Receptors into Nanometric Lipid Particles. Biochemistry 2016, 55, 38-48. [CrossRef] [PubMed]

15. Damian, M.; Pons, V.; Renault, P.; M’Kadmi, C.; Delort, B.; Hartmann, L.; Kaya, A.I.; Louet, M.; Gagne, D.; Ben Haj Salah, K.; et al. GHSR-D2R heteromerization modulates dopamine signalling through an effect on G protein conformation. Proc. Natl. Acad. Sci. USA 2018, 115, 4501-4506. [CrossRef] [PubMed]

16. Vandenberg, J.I.; Perry, M.D.; Perrin, M.J.; Mann, S.A.; Ke, Y.; Hill, A.P. hERGK(+) channels. Structure, function and clinical significance. Physiol. Rev. 2012, 92, 1393-1478. [CrossRef]

17. Vandenberg, J.I.; Perozo, E.; Allen, T.W. Towards a Structural View of Drug Binding to hERG K+ Channels. Trends Pharmacol. Sci. 2017, 38, 899-907. [CrossRef]

18. Priest, B.; Bell, I.M.; Garcia, M. Role of hERG potassium channel assays in drug development. Channels 2014, 2, 87-93. [CrossRef]

19. Foo, B.; Williamson, B.; Young, J.C.; Lukacs, G.; Shrier, A. hERG quality control and the long QT syndrome. J. Physiol. 2016, 594, 2469-2481. [CrossRef]

20. Kalyaanamoorthy, S.; Barakat, K.H. Development of Safe Drugs. The hERG Challenge. Med. Res. Rev. 2018, 38, 525-555. [CrossRef]

21. Subbiah, R.N.; Clarke, C.E.; Smith, D.J.; Zhao, J.; Campbell, T.J.; Vandenberg, J.I. Molecular basis of slow activation of the human ether-a-go-go related gene potassium channel. J. Physiol. 2004, 558, 417-431. [CrossRef] 
22. Cheng, Y.M.; Claydon, T.W. Voltage-dependent gating of HERG potassium channels. Front. Pharmacol. 2012, 3, 83. [CrossRef]

23. Ceccarini, L.; Masetti, M.; Cavalli, A.; Recanatini, M. Ion conduction through the hERG potassium channel. PLoS ONE 2012, 7, e49017. [CrossRef]

24. Wang, W.; MacKinnon, R. Cryo-EM Structure of the Open Human Ether-à-go-go-Related K+ Channel hERG. Cell 2017, 169, 422-430. [CrossRef]

25. Hausammann, G.J.; Grütter, M.G. Chimeric hERG channels containing a tetramerization domain are functional and stable. Biochemistry 2013, 52, 9237-9245. [CrossRef]

26. Harbury, P.B.; Zhang, T.; Kim, P.S.; Alber, T. A switch between two-, three- and four-stranded coiled coils in GCN4 leucine zipper mutants. Science 1993, 262, 1401-1407. [CrossRef]

27. Bernaudat, F.; Frelet-Barrand, A.; Pochon, N.; Dementin, S.; Hivin, P.; Boutigny, S.; Rioux, J.-B.; Salvi, D.; Seigneurin-Berny, D.; Richaud, P.; et al. Heterologous expression of membrane proteins. Choosing the appropriate host. PLoS ONE 2011, 6, e29191. [CrossRef]

28. Long, S.B.; Tao, X.; Campbell, E.B.; MacKinnon, R. Atomic structure of a voltage-dependent K+ channel in a lipid membrane-like environment. Nature 2007, 450, 376-382. [CrossRef]

29. Hartmann, L.; Kugler, V.; Wagner, R. Expression of Eukaryotic Membrane Proteins in Pichiapastoris. Meth. Mol. Biol. 2016, 1432, 143-162.

30. Bornert, O.; Alkhalfioui, F.; Logez, C.; Wagner, R. Overexpression of membrane proteins using Pichiapastoris. Curr. Protoc. Prot. Sci. 2012. [CrossRef]

31. André, N.; Cherouati, N.; Prual, C.; Steffan, T.; Zeder-Lutz, G.; Magnin, T.; Pattus, F.; Michel, H.; Wagner, R.; Reinhart, C. Enhancing functional production of $\mathrm{G}$ protein-coupled receptors in Pichiapastoris to levels required for structural studies via a single expression screen. Prot. Sci. 2006, 15, 1115-1126. [CrossRef]

32. Hite, R.K.; Yuan, P.; Li, Z.; Hsuing, Y.; Walz, T.; MacKinnon, R. Cryo-electron microscopy structure of the Slo2.2 $\mathrm{Na}(+)$-activated $\mathrm{K}(+)$ channel. Nature 2015, 527, 198-203. [CrossRef]

33. Midgett, C.R.; Madden, D.R. Breaking the bottleneck. Eukaryotic membrane protein expression for high-resolution structural studies. J. Struct. Biol. 2007, 160, 265-274. [CrossRef]

34. Andréll, J.; Tate, C.G. Overexpression of membrane proteins in mammalian cells for structural studies. Mol. Membr. Biol. 2013, 30, 52-63. [CrossRef]

35. Ficker, E.; Jarolimek, W.; Kiehn, J.; Baumann, A.; Brown, A.M. Molecular determinants of dofetilide block of HERG K+ channels. Circ. Res. 1998, 82, 386-395. [CrossRef]

36. Gomez-Martinez, M.; Schmitz, D.; Hergovich, A. Generation of stable human cell lines with Tetracycline-inducible (Tet-on) shRNA or cDNA expression. JoVE 2013, 73, e50171. [CrossRef]

37. Gong, Q.; Anderson, C.L.; January, C.T.; Zhou, Z. Role of glycosylation in cell surface expression and stability of HERG potassium channels. Am. J. Physiol. Heart Circ. Physiol. 2002, 283, H77-H84. [CrossRef]

38. Molbaek, K.; Scharff-Poulsen, P.; Helix-Nielsen, C.; Klaerke, D.A.; Pedersen, P.A. High yield purification of full-length functional hERG K+ channels produced in Saccharomyces cerevisiae. Microb. Cell Fact. 2015, 14, 15. [CrossRef]

39. Anandan, A.; Vrielink, A. Detergents in Membrane Protein Purification and Crystallisation. Adv. Exp. Med. Biol. 2016, 922, 13-28.

40. Le Maire, M.; Champeil, P.; Møller, J.V. Interaction of membrane proteins and lipids with solubilizing detergents. Biochim. Biophys. Acta Biomembr. 2000, 1508, 86-111. [CrossRef]

41. Bhuyan, A.K. On the mechanism of SDS-induced protein denaturation. Biopolymers 2010, 93, $186-199$. [CrossRef]

42. Agasid, M.T.; Wang, X.; Huang, Y.; Janczak, C.M.; Bränström, R.; Saavedra, S.S.; Aspinwall, C.A. Expression, purification and electrophysiological characterization of a recombinant, fluorescent Kir6.2 in mammalian cells. Prot. Express. Purif. 2018, 146, 61-68. [CrossRef]

43. Thomas, J.A.; Tate, C.G. Quality control in eukaryotic membrane protein overproduction. J. Mol. Biol. 2014, 426, 4139-4154. [CrossRef]

44. Chipot, C.; Dehez, F.; Schnell, J.R.; Zitzmann, N.; Pebay-Peyroula, E.; Catoire, L.J.; Miroux, B.; Kunji, E.R.; Veglia, G.; Cross, T.A.; et al. Perturbations of native membrane protein structure in alkyl phosphocholine detergents: A critical assessment of NMR and biophysical studies. Chem. Rev. 2018, 118, 3559-3607. [CrossRef] [PubMed] 
45. Zou, A.; Curran, M.E.; Keating, M.T.; Sanguinetti, M.C. Single HERG delayed rectifier K+ channels expressed in Xenopus oocytes. Am. J. Physiol. 1997, 272, H1309-H1314. [CrossRef]

46. Oshima, A.; Hirano-Iwata, A.; Mozumi, H.; Ishinari, Y.; Kimura, Y.; Niwano, M. Reconstitution of human ether-a-go-go-related gene channels in microfabricated silicon chips. Anal. Chem. 2013, 85, 4363-4369. [CrossRef]

47. Yu, Z.; IJzerman, A.P.; Heitman, L.H. Kv 11.1 (hERG)-induced cardiotoxicity: A molecular insight from a binding kinetics study of prototypical Kv 11.1 (hERG) inhibitors. Br. J. Pharmacol. 2015, 172, 940-955. [CrossRef]

(C) 2019 by the authors. Licensee MDPI, Basel, Switzerland. This article is an open access article distributed under the terms and conditions of the Creative Commons Attribution (CC BY) license (http://creativecommons.org/licenses/by/4.0/). 